\title{
THE CHEMICAL COMPOSITION OF SOME SORGHUM GENOTIPES FOR GRAINS CULTIVATED IN THE CENTER OF MOLDOVA
}

\author{
SIMONA - FLORINA ISTICIOAIA ${ }^{* 1}$, OANA MIRZAN ${ }^{1}$, DIANA POPA, \\ MARGARETA NAIE ${ }^{1}$, VALENTIN VLADUT ${ }^{2}$, IULIAN VOICEA ${ }^{2}$
}

${ }^{1}$ A.R.D.S. Secuieni, Principala 371, Neamt, 617415, Romania

${ }^{2}$ I.N.M.A. Bucuresti, B-dul Ion Ionescu de la Brad 6, sector1, Bucuresti, 013811, Romania

\begin{abstract}
In the lab, three sorghum hybrids for grains cultivated in the Center of Moldova were analyzed qualitatively, two of them having white grains, and one having red grains. Two of the hybrids, one with white grains (Albanus) and one with red grains (Alize) came from Euralis SAS France, and the third, with white grains, came from N.A.R.D.I. Fundulea Romania (Fundulea 32). The results obtained from the laboratory investigations indicated that the variation of the chemical composition of the sorghum grain depending on the cultivated hybrid.
\end{abstract}

Keywords: chemical composition, enzymatic cellulose activity, sorghum grains

\section{INTRODUCTION}

Sorghum is a species of major importance in human nutrition, providing food to the population of 30 African and Asian countries (more than 500 million people). Due to its high drought tolerance and its ability to withstand high temperatures and to efficiently exploit water in Africa, sorghum is the basis of food safety [1]. Unfortunately, the cultivation of sorghum in this area is made with precarious technology in a subsistence farming system, Africa producing one-third of the world's sorghum but having the lowest productivity/ha [2]. Worldwide, more than $50 \%$ of the sorghum production is used for animal nutrition [3], but there is currently increasing interest in the use of sorghum in human food, especially as a source of gluten-free food and preparation of beverages [4-5].

A great advantage of sorghum is that it is a versatile species that can be cultivated under various pedoclimatic conditions [6]. This advantage has increased the importance of species currently being seen globally as a solution to mitigate the negative effects of climate change $[7,8,9,10]$.

In the endosperm of the sorghum grain we find carbohydrates, proteins and small amounts of fat and fiber. The carbohydrate concentration in the endosperm varies between 65 and $90 \%$, the starch being major. Protein content varies between 7 and $15 \%$ and includes albumin, globulin, caffirine and gluteline. As with other cereals, protein is deficient in essential lysine [11]. The sorghum kernel is a source of B complex vitamins, including thiamine, riboflavin, niacin, pyridoxine, pantothenic acid, biotin and folic acid and other vitamins such as A, D, $\mathrm{E}$ and $\mathrm{K}[2]$. The sorghum also contains minerals such as potassium, magnesium, iron, zinc and copper but has a low calcium and sodium content [12].

\footnotetext{
*Corresponding author, email: simonapochi@yahoo.com, simona.pochiscanu@ @scda.ro

(c) 2018 Alma Mater Publishing House
} 


\section{MATERIAL AND METHOD}

The analyzed samples come from the experimental field of S.C.D.A. Secuieni where in $2015-2017$ was placed a monofactorial experience, in three repetitions, by randomized block method. The experience was aimed at analyzing a number of three sorghum hybrids for grain predominated on the Romanian market. Two of the hybrids, one with white kernel (Albanus) and one with red kernel (Alize) came from Euralis Semences SRL and the third, with white kernel, from I.N.C.D.A. Fundulea, Romania (Fundulea 32).

Biochemical analyzes of sorghum were carried out using the NIR type analyzer, Dickey John, INSTALLAB 600. In the laboratory the percentage content of sorghum grain was determined in: ADF, NDF, fibers, ash, saturated and unsaturated fats, protein, starch and sugar. For each compound, three determinations were performed and the final results are the mean of these determinations.

\section{RESULTS AND DISCUSSION}

The results obtained from the laboratory investigations indicated that the chemical composition of the sorghum grain varied according to the cultivated hybrid.

In recent years, concentrated feeds are tested in laboratories to evaluate neutral detergent (NDF) content and soluble fiber content (ADF). Fractions extracted for NDF are hemicellulose, cellulose and lignin, and cellulose and lignin in the case of ADF.

From Table 1 we can see that these two components differ from one hybrid to another, with values between 7.66 $\%$ (Alize) and $8.78 \%$ (Albanus) in the case of the ADF and $2.97 \%$ (Albanus) - $3.06 \%$ (Alize) in the case of NDF. Compared with the control variant, Fundulea 32, ADF increases were recorded in the version sown with the hybrid Albanus, these being statistically assured and interpreted as very significant.

The fiber content ranged from $2.12 \%$ (Albanus) to $2.24 \%$ (Fundulea 32) and the ash percentage from $1.42 \%$ (Alize) to $1.44 \%$ (Fundulea 32) (Table 1).

Table 1. Results obtained regarding the influence of the hybrid on grain quality at Sorghum bicolor L., 2015-2017.

\begin{tabular}{|l|c|c|c|c|}
\hline \multirow{2}{*}{ Hybrid } & \multicolumn{4}{|c|}{ Contents of sorghum grain in: } \\
\cline { 2 - 5 } & ADF \% & NDF \% & Fiber \% & Ash \% \\
\hline Fundulea 32 & $7.72^{\mathrm{Ct}}$ & $3.02^{\mathrm{Ct}}$ & $2.24^{\mathrm{Ct}}$ & $1.44^{\mathrm{Ct}}$ \\
\hline Alize & 7.66 & 3.06 & 2.18 & 1.42 \\
\hline Albanus & $8.78^{* * * *}$ & 2.97 & 2.12 & 1.43 \\
\hline LSD 5 \% (\%) & 0.07 & 0.10 & 0.12 & 0.02 \\
LSD 1 \% (\%) & 0.09 & 0.13 & 0.16 & 0.03 \\
LSD 0,1 \% (\%) & 0.12 & 0.18 & 0.21 & 0.04 \\
\hline${ }^{*}$ significant; ${ }^{* *}$ distinct \\
ooo significant; ${ }^{* * * *}$ very \\
negative very significant
\end{tabular}

Fats in feed are very important because they have the ability to produce twice as much energy as carbohydrates or proteins. In addition, fats make food more succulent. The results have shown that sorghum grain is richer in saturated fats compared to unsaturated fats.

The percentage of saturated fats varied from $4.72 \%$ (Albanus) to $4.91 \%$ (Alize), and the unsaturated ones were present in a percentage of $3.76 \%$ (Fundulea 32) and $3.82 \%$ (Alize). Compared with the control variant (Fundulea 32), the Alize hybrid showed significant increases in both saturated and unsaturated fats (Table 2).

Experimental variants were characterized by a fairly high protein content, ranging from $8.96 \%$ (Alize) and $9.91 \%$ (Albanus). Compared with the control variant, the Albanus hybrid made a protein increase very significant, and the difference made by the Alize hybrid was very negative (Table 2). 
Table 2. Results obtained regarding the influence of the hybrid on grain quality at Sorghum bicolor L., 2015-2017.

\begin{tabular}{|l|c|c|c|c|c|}
\hline \multirow{2}{*}{ Hybrid } & \multicolumn{5}{|c|}{ Contents of sorghum grain in: } \\
\cline { 2 - 6 } & Saturated fat\% & $\begin{array}{c}\text { Unsaturated fat. } \\
\%\end{array}$ & Protein & Starch & Sugar \\
\hline Fundulea 32 & $4.77^{\text {Ct. }}$ & $3.76^{\text {Ct. }}$ & $9.43^{\text {Ct. }}$ & $66.87^{\text {Ct. }}$ & 2.30 \\
\hline Alize & $4.91^{*}$ & $3.82^{*}$ & $8.96^{\text {ooo }}$ & $66.18^{\circ}$ & 2.32 \\
\hline Albanus & 4.72 & 3.78 & $9.91^{* * *}$ & $64.93^{\text {ooo }}$ & $2.54^{* * *}$ \\
\hline LSD 5 \% (\%) & 0.12 & 0.05 & 0.18 & 0.51 & 0.09 \\
LSD 1 \% (\%) & 0.16 & 0.07 & 0.24 & 0.70 & 0.13 \\
LSD 0.1\%(\%) & 0.21 & 0.09 & 0.32 & 0.93 & 0.17 \\
\hline
\end{tabular}

The Albanus hybrid was also marked by a higher sugar content, the increase being very significant compared to the control variant. Starch content ranged from $64.93 \%$ (Albanus) to $66.87 \%$ (Fundulea 32) (Table 2).

Enzymatic cellulose activity was superior to Albanus hybrid and ranged from $87.61 \%$ (Alize) to $88.29 \%$ (Albanus) (Table 3).

Table 3. Enzymatic cellulose activity at Sorghum bicolor L., 2015 - 2017.

\begin{tabular}{|c|c|c|c|}
\hline \multirow{2}{*}{ Enzymatic cellulose activity (\%) } & \multicolumn{3}{|c|}{ Hybrid } \\
\cline { 2 - 4 } & Fundulea 32 & Alize $^{\text {o }}$ & Albanus \\
\cline { 2 - 4 } & 88.20 & 87.61 & 88.29 \\
\hline LSD 5\% (\%) & \multicolumn{2}{c}{0.54} \\
LSD 1\%(\%) & & 0.74 \\
LSD 0.1\%(\%) & 1.02 \\
\hline
\end{tabular}

\section{CONCLUSIONS}

Albanus hybrid has been found to have a higher content in ADF (8.78 \%), protein $(9.91 \%)$ and sugar $(2.54 \%)$, while Fundulea 32 hybrid is remarkable higher in fiber $(2.24 \%)$, ash (1.44\%) and starch (66.87\%). Also, enzyme cellulose activity is better for Albanus hybrid $(88.29 \%)$. Alize hybrids are richer than other hybrids in NDF $(3.06 \%)$ and fats (4.91\% saturated and $3.82 \%$ unsaturated).

\section{ACKNOWLEDGEMENT}

This work was supported by a grant of the Romanian Minister of Research and Innovation CCDI - UEFISCDI, project number 9/PCCDI/2018 within PNCDI III.

\section{REFERENCES}

[1] International Crops Research Institute for the Semi-Arid Tropics (Accessed:31-7-2015), Sorghum (Sorghum bicolor L. Moench), 2015.

[2] Taylor, J.R.N., Overview: importance of sorghum in Africa, In AFRIPRO workshop on the proteins of sorghum and millets: enhancing nutritional and functional properties for Africa, Pretioria, South Africa, 2-4 April 2003, Belton, P.S. and Taylor, J.R.N. eds., 2003.

[3] FAO, Sorghum and millets in human nutrition, Rome, Italy, 1995.

[4] O'Hara, I., Kent, G., Alberston, P., Harrison, M., Hobson, P., McKenzie, N., Sweet sorghum:opportunities for a new, renewable fuel and food industry in Australia, Report No: RIRDC Publication N. 13/087, RIRDC Project No. PRJ-005254, Rural Industries Research and Development Corporation, 2013.

[5] Norwood, C., Chinese toast australian sorghum, Grains Research and Development corporation, 2015.

[6] Cothren, J.T., Matocha, J.E., Clark, L.E., Chapter 3.2: Integrated crop management for sorghum, In: Sorghum: Origin, history, technology and production, Smith, C.W., Frederiksen R.A., eds. John Wiley and Sons New York, 2000, p. 409-442. 
[7] Buburuz, A.A., Popa, L.D., The productivity of some monoecious hemp varieties (for fiber and mixte) under the center of Moldavia ecopedoclimatic conditions, Journal of Engineering Studies and Research, vol. 23, no. 2, 2017, p. 7- 11.

[8] Naie, M., Mirzan, O., Dobrea, D.I., Researches regarding the influence of the nutrition space at Dracocephalum Moldavica 1. (Dragonhead) species cultivated under the conditions of A.R.D.S. Secuieni, Journal of Engineering Studies and Research, vol. 23, no. 2, 2017, p. 16-21.

[9] Ursache, P.L., Trotus, E., Buburuz, A.A., Observations concerning the harmful Entomofauna from winter rapeseed crops in the conditions of Central of Moldava, between years 2014-2017, Journal of Engineering Studies and Research, vol. 23, no. 2, 2017, p. 33-41.

[10] Irimia, O., Nedeff, V., Panainte Lehăduş, M., Tomozei C., Experimental study concerning the distribution of granular particle shape from a filter layer, Journal of Engineering Studies and Research, vol. 22, no. 1, 2016, p. 64-71.

[11] Dicko, M.H., Gruppen, H., Traoré, A.S., Voragen, A.G.J., Van Berkel, W.J.H., Sorghum grain as human food in Africa: relevance of content of starch and amylase activities, African Journal of Biotechnology, no. 5, 2006, p. 384-395.

[12] Awika, M.A., Rooney, L.W., Sorghum phytochemicals and their potential impact on human health, Phytochemistry, no. 65, 2004, p. 1199-1221. 